\title{
Telework After COVID: A “Silver Lining” for Workers with Disabilities?
}

\author{
Lisa A. Schur ${ }^{1} \cdot$ Mason Ameri ${ }^{2} \cdot$ Douglas Kruse $^{1}$ (i) \\ Accepted: 21 October 2020 / Published online: 6 November 2020 \\ (c) Springer Science+Business Media, LLC, part of Springer Nature 2020
}

\begin{abstract}
Purpose The COVID pandemic was a severe blow to all workers, but it may ultimately have a silver lining for some workers with disabilities if it makes work from home easier and more acceptable. In addition, the pandemic is shaking up traditional workplace structures and causing employers to rethink how essential tasks can be done, which may broaden their views of workplace accommodations. We assess the potential for the pandemic to improve employment opportunities for people with disabilities. Methods This article analyzes pre-COVID data on disability and home-based work from three representative data sources-the American Community Survey, American Time Use Survey, and Current Population Survey. We employ both cross-tabulations and regressions to predict work at home. Results We find that workers with disabilities are more likely than those without disabilities both to work primarily from home and to do any work at home. This is true for both employees and self-employed workers. Workers with disabilities face similar wage gaps in on-site and home-based work, indicating that while increased availability of home-based work may create more employment opportunities for workers with disabilities, it is unlikely to erase wage disparities. While workers with disabilities are currently more likely to be working primarily from home, only $34 \%$ are in occupations with high potential for home-based work, compared to $40 \%$ of workers without disabilities. Conclusions Workers with disabilities are currently more likely to work from home and many may benefit from expanded work-at-home opportunities, but the types of jobs they hold constrain this potential. Research is needed to see how home-based work evolves as the economy recovers from the pandemic over the next several years.
\end{abstract}

Keywords Right to employment $\cdot$ Employment insecurity $\cdot$ Discrimination $\cdot$ Pay equity $\cdot$ Work location

\section{Introduction}

Working from home became the "new normal" for many workers during the COVID-19 pandemic. Millions of people sheltered in place, staying at home and working remotely, and connecting to colleagues through email, cell phones, and web-based video conferences. But what will happen following the crisis? Will we return to the "old normal" ways

Douglas Kruse

dkruse@smlr.rutgers.edu

Lisa A. Schur

lschur@smlr.rutgers.edu

Mason Ameri

Mason.ameri@rutgers.edu

1 School of Management and Labor Relations, Rutgers University, New Brunswick, NJ, USA

2 Rutgers Business School, Rutgers University, New Brunswick, NJ, USA of working, or will more employers recognize that working from home can benefit both themselves and employees?

The answers may be especially crucial for millions of people with disabilities who are currently non-employed, but who want to work [1]. The pandemic-related upswing in working from home may have long-term benefits for many workers, especially workers with disabilities. Apart from the value of social distancing during the pandemic, there are long-recognized costs and benefits to working at home [2]. One principal advantage is the flexibility it provides. Flexibility is of particular value for people who have physical or mental impairments that make it more challenging to work in traditional workplace settings, as well as for those who care for young infants or older relatives. Reducing commuting time and expense is valuable for all workers, and it may be especially beneficial for people with mobility impairments who find it difficult or costly to travel outside the home.

In addition, work from home has unique benefits for those with health issues that require frequent breaks from work, 
such as those with mental or cognitive issues who can benefit from being away from a stressful environment [3], or who need to remain close to medical equipment and therapeutics at home. It may also help people who have recurring medical appointments, unpredictable flare-ups of their conditions, or other issues that make working consistently at a job site difficult, if not impossible.

Potential downsides for all workers include greater social isolation, increasingly blurred lines between work and home life, and being "out of sight, out of mind" for promotion and training opportunities. All of these drawbacks may particularly impact more marginalized groups such as people with disabilities, women, people of color, and the LGBTQ community [4].

For employers, potential downsides of working from home include increased difficulty monitoring employee work, and possibly lower productivity and morale if employees become too distracted at home and disconnected from peers. On the other hand, worker productivity may increase if workers are less stressed by commuting and less distracted by co-worker interruptions. Their satisfaction may also increase, leading to lower employee turnover.

There is policy interest in expanding work-at-home options for workers with disabilities. The World Health Organization specifically endorsed telework for people with disabilities during the pandemic [5], and scholars have argued that the U.S. Equal Employment Opportunity Commission (EEOC) should update its guidance on telework to reduce employers' ability to present an undue hardship defense with respect to telework accommodations [6].

What are the implications of the pandemic-related upswing in working from home? Will this lead to increased work opportunities for people with disabilities? We use three pre-COVID datasets to explore patterns and trends in home-based work for workers with and without disabilities. The datasets measure both work done primarily at home and any work done at home. Second, we estimate how the disability wage gap may vary between home-based workers and non-home-based workers to see whether home-based work may alleviate or exacerbate wage disparities. Third, we explore the potential for home-based work among people with disabilities by analyzing the current occupational distribution in relation to recent occupation-based estimates of how many tasks can be done at home. Fourth, we use these findings for informed speculation on the potential for increased employment of people with disabilities due to the increased availability of work from home (and potentially other work accommodations) as employers rethink how to organize work after the pandemic. Finally, we lay out a research agenda for exploring post-COVID patterns of home-based work for workers with and without disabilities.

\section{Literature Review}

\section{Employment of People with Disabilities}

In 2019, less than a third (30.9 percent) of working-age people with disabilities were employed, compared to three-quarters (74.6 percent) of people without disabilities [7]. The figures for workers both with and without disabilities had increased since the end of the previous recession in 2010, but it is noteworthy that the disability employment rate grew especially quickly in the increasingly tight labor markets of 2015-2019. The disability employment rate rose by 4.0 points from 2015 to 2019, compared to an increase of 2.4 points for workers without disabilities. This relative advance was, however, largely undone by the greater employment losses of workers with disabilities in the 2020 COVID recession. The total employment of people with disabilities decreased by $11.2 \%$ from February to July 2020, compared to a decrease of $6.7 \%$ for people without disabilities. ${ }^{1}$

Why are people with disabilities less likely to be employed? While some individuals with disabilities have limitations that make gainful work difficult, many face other barriers to employment [8]. Employer audit studies that we and others have conducted show that employers are less likely to express interest in job applications from people with disabilities, even when their resumes are identical to those of applicants without disabilities and the disabilities are irrelevant to job performance (e.g., a person with a spinal cord injury applying for an accounting job) [9-11].

Other studies show that once hired, many workers with disabilities face negative stereotypical attitudes and expectations from managers, supervisors, and co-workers that limit their career growth and the quality of their work-life, including more negative treatment from management [12, 13]. While most co-workers support disability accommodations, these can sometimes generate jealousy and resentment [14]. Employees with disabilities also face a gap in pay after accounting for productive characteristics such as education and job experience $[13,15,16]$. They also express feelings of lower job security and are more likely to be laid off by employers when times are bad [13, 17]. In short, like other members of marginalized groups, workers with disabilities appear to be "last hired, first fired." These disparities are linked to lower job satisfaction among workers with disabilities, although they have similar levels of organizational commitment and turnover intention as have workers without disabilities [13].

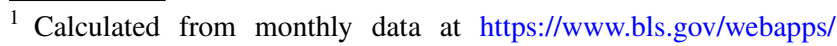
legacy/cpsatab6.htm.
} 


\section{Working from Home}

A key concern for employers is whether productivity suffers when their employees work from home. A largescale randomized field experiment in a Chinese company addressed this concern. Half the workforce was randomly assigned to telecommuting while the other half kept reporting to the office [18]. Worker productivity was $13 \%$ higher among telecommuters. In addition, it was reported that their satisfaction was higher and turnover was lower. The results appear to be validated by a study finding that productivity did not go down after the shift to remote work in the pandemic [19], and by other pre-pandemic studies of remote work reporting an increase in work performance [20, 21]. Amid Covid-19 and workplace shutdowns, many businesses recognized that this pandemic increased creativity and innovation among their employees and have chosen to extend remote work options permanently [19, 22].

This finding is supported by a study of Flemish employees' telework perceptions during the Covid-19 crisis [23]. It found that workers mainly had a positive outlook on remote work, stating that they were more efficient and less exhausted. The overwhelming majority also said that telework and remote conferencing would become permanent features of their work. However, some people expressed fears that telework would diminish their promotion opportunities and weaken ties with their co-workers and employers.

Because it challenges the very idea of how work should be organized, the merits of telework have been argued for decades [24]. Some businesses have expressed concerns about reduced teamwork and collaboration among workers [25], while others have been attracted by the value telework adds. For example, employers can gain access to valuable human resources that would otherwise be difficult to recruit if not for work flexibility [26]. To that end, telework is especially crucial for some people who want to work but often cannot due to constraints from other aspects of their lives, such as child and elder care [24].

A competing argument points out that telework may blur the divide between work and home roles, which can increase stress and reduce job performance [27]. Some believe that telework is not as effective when home responsibilities present themselves, as some people are unable to establish boundaries between the two [28]. Still, research finds that the intersection of telework and home-life does not necessarily produce unfavorable results. It seems that those who have greater home responsibilities are actually more productive teleworkers than those without [29]. In other words, teleworking may lead workers to organize their lives more efficiently. They may, for example, compartmentalize household chores and job duties and manage them more effectively [30]. This idea is supported in research by Madsen
[31], who found that telework led to a reduction in both work and family conflict and stress.

In the following section, we discuss how telework may be considered a form of providing reasonable accommodation for people with disabilities, which can increase employment rates.

\section{Disability and Working from Home}

A recent review finds 17 studies over the 2000-2020 period that focused on telework and disability; it divides them up into studies that focus on overall employment opportunities, work patterns and accommodations, performance, policy, and work-life balance [32]. Most of the studies discussed the potential advantages and issues surrounding telework and disability without using or developing new empirical data. The authors of the review conclude there is a "scarcity of empirical data that can provide an in-depth understanding of the lived experience of those two groups [workers with and without disabilities] of home-based teleworkers" [32].

Among the empirical studies, a survey of 373 employed people with disabilities that measured accommodation use finds that telework's main benefits as a disability accommodation are the reduction of pain- and fatigue-related barriers to traditional employment [33]. A European study finds that telework is linked to higher job satisfaction and lower absenteeism among workers with disabilities [34]. In addition to viewing telework as a form of disability accommodation, Moon et al. [35] find that employees in general see telework as a way to achieve greater work-life balance and as a strategy for reducing pain and fatigue not formally recognized as disability-related. In turn, employers view telework not only as a disability-related accommodation, but also as a way to achieve broader job restructuring goals [36, 37].

The positive and negative aspects of telework for people with disabilities are explored by Baker et al. [38], who report that while telework can provide increased opportunities for hiring people with disabilities, it may also "place severe constraints on the type of work, workplace environment and the interactions, and accumulation of social capital for people with disabilities" [p. 42]. The authors are concerned about finding ways to reduce the social isolation experienced by many teleworkers and increase their participation in the workplace community, especially because people with disabilities experience greater social isolation in general. Two case studies of successful accommodation through telework are presented by West and Anderson [39].

McNaughton et al. also look at the pros and cons of telework, focusing on people who use augmentative or alternative communication means [40]. They find that the people in their study identified the elimination of travel time and flexible work schedules as a major benefit of telework, while 
also expressing concerns about feeling isolated and the difficulty of separating their home and work lives.

The question of whether courts treat telework as a reasonable accommodation is obviously relevant. Mulvaney examines whether the current growth of telework will have an impact on U.S. courts' reluctance to interpret telework as a "reasonable accommodation" under the Americans with Disabilities Act [41]. Employer arguments against telework as a disability accommodation may be undercut now that many employers have allowed their employees to work from home during the pandemic. Mulvaney cites a 2019 Bloomberg Law study that finds that historically, most courts have sided with employers and have ruled that telework is not a reasonable accommodation because it prevents employees from performing an essential job function, namely on-site attendance. Now that many employers require people to work from home, it may become more challenging for companies to claim that telework prevents employees from doing essential job duties [6]. On the other hand, courts may see that the pandemic is a unique circumstance and continue to side with employers by ruling that telework is not a reasonable accommodation and that physical presence is an essential function of the job. This may be especially true if work quality or efficiency suffers during the pandemic.

\section{Data}

To shed light on home-based work for people with disabilities, we make use of three representative surveys, all conducted by the Census Bureau. The American Community Survey (ACS) implemented six disability questions in 2008 that distinguish among the broad categories of visual, hearing, cognitive, and mobility impairments, and two activity limitations (difficulty with self-care, and difficulty going outside alone). We use its data from 2009 through 2018. Following the Census Bureau method, people are defined as having a disability if they respond yes to one or more of the six questions. We do not have information on the time of onset of disability, so we cannot distinguish between congenital and acquired disabilities. We restrict our analysis to employed civilians who worked in the prior week and answered the commuting question: "How did this person usually get to work LAST WEEK?" Those who responded "worked at home" are counted as primarily working at home. Across 2009-2018 our sample includes 13,019,338 workers without disabilities and 810,897 workers with disabilities.

The second survey we use is the American Time Use Survey (ATUS) over the 2008-2018 period. This is based on the representative Current Population Survey (CPS). Five months after a household leaves the CPS rotation, one person in the household is surveyed about every activity they engaged in during one day. The CPS and ACS use the same disability questions, so we define disability in the same way in both datasets. A limitation of the ATUS is that the disability measure comes from the earlier CPS survey; therefore, there is at least a 5-month lag between the disability measure and the ATUS work-at-home measure, which makes the disability measure less reliable as there is time for the onset, disappearance, or change of severity of some disabilities. We use the ATUS files matched to CPS for 2008 to 2018, which contain 39,380 observations on workers with disabilities and 1,413 on workers without disabilities. We define someone as doing work at home if they described any activity of working on their primary job during the reference day, and doing it in "respondent's home or yard." A general exploration of telework using the ATUS is provided by Pabilonia and Vernon [42].

The third survey we use is the CPS Disability Supplement done in May 2012 and July 2019. This supplement asked a variety of questions to explore the employment situation of people with disabilities, including questions identifying any work at home ("Do you do any work at home for your job or business?"), whether the home-based work is paid, whether it is based on a formal arrangement with the employer, and reasons for home-based work. The combined supplements have samples of 93,281 employed people without disabilities and 3,896 with disabilities.

An important note is that the ACS and ATUS measures of home-based work are very different, with the ACS measuring whether someone worked primarily from home, and the ATUS measuring whether someone did any work from home for their main job during the reference day. The CPS Supplement includes both of these measures.

Most of our tables are based on simple cross tabulations. In Tables 4 and 7, however, we present linear probability models that predict the likelihood of home-based work, with controls including personal characteristics along with detailed occupation dummies. Including occupation dummies means the estimates can be seen as comparisons of workers with and without disabilities within the same occupation. Also, in Table 8 we present the results of standard wage equations, using personal characteristics, labor market experience, and detailed occupation to predict the natural logarithm of wages. The results can be easily translated into average percentage wage differentials between home-based workers with and without disabilities, and between homebased and on-site workers with disabilities.

\section{Results}

\section{Working Primarily From Home}

Workers with disabilities are more likely than those without disabilities to work primarily from home. As shown in Table 1, an average of $5.7 \%$ did so in the 2009-2018 period, 
Table 1 Work primarily at home by disability status, 2009-2018

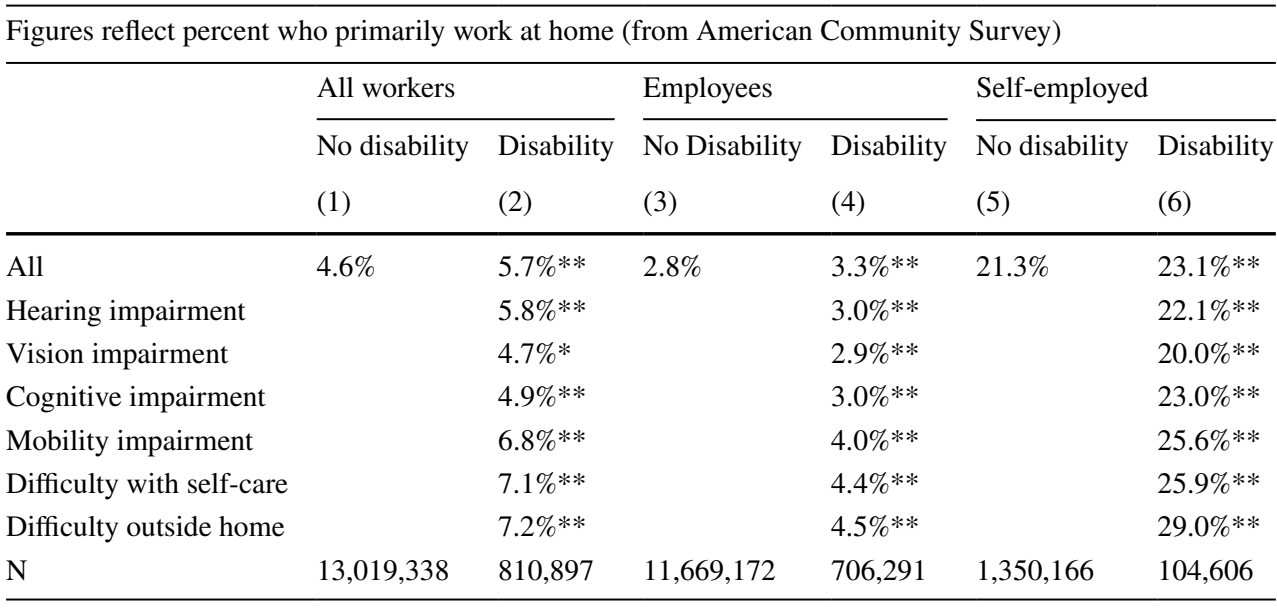

*Significant difference from non-disability sample at $\mathrm{p}<0.05$

$* * \mathrm{p}<0.01$ compared to $4.6 \%$ of workers without disabilities (columns 1 and 2). The rates of home-based work are especially high among workers with mobility impairments $(6.8 \%)$ or difficulty with activities inside the home $(7.1 \%)$ or outside the home (7.2\%) (column 2). The differences by type of disability are illustrated in Fig. 1. The disability gap is smaller but still highly significant when confined just to employees (3.3\% compared to $2.8 \%$, in columns 3 and 4 ), and expands slightly and remains significant when limited only to the self-employed (23.1\% compared to $21.3 \%$, in columns 5 and $6)$.

The disability gap is maintained across almost all personal characteristics in the breakdowns in Table 2. Workers with disabilities remain more likely than those without disabilities to primarily work at home across gender, race/ ethnic, and education categories, and regardless of whether they live alone, live with children under age 18 , live with elders age 65 or older, or live in a house with Internet access (columns 1 and 2). The exception is that there are no significant differences by disability status for middle-aged workers (age 35-49 or 50-64), so the disability gap is concentrated among younger and older workers (18-34, and 65 plus). The younger cohort of workers with disabilities may be more challenged in finding employment and more likely to work from home as they look for stable work. In comparison, the older cohort of workers with disabilities may be more likely to have retired from prior jobs and opted for telework as a convenience. Also, it is possible that middle-aged workers with disabilities are more motivated to work on site since they are at the peak of their earnings capacity and do not want to receive a wage penalty for working from home.

The occupational distribution does not explain the disability gap in home-based work. As shown in Table 3, workers with disabilities are significantly more likely to work primarily at home in each of the six major occupations.
These relationships are tested more rigorously in Table 4 using linear probability regressions that control for demographic characteristics and detailed occupation (Probit regressions produced similar results). As can be seen, workers with disabilities were significantly more likely to be working primarily at home, both overall and when confined to employees (columns 1 and 4). Controlling for other variables, workers with vision or hearing impairments are less likely than workers without disabilities to work primarily at home. In contrast, workers with mobility impairments and difficulty outside the home are more likely to do so (columns 2 and 5).

How is home-based work changing over time? Figure 2 shows that workers with disabilities were more likely to work primarily at home over the $2009-2018$ period. The home-based work rates increased for both workers with disabilities (5.3\% to $6.0 \%$ after smoothing) and workers without disabilities (4.0\% to $5.2 \%$ ) over this period, but the disability gap narrowed. Table 4 confirms these trends, showing a positive trend in home-based work for both groups, but a more positive trend for workers without disabilities. Note that while the disability-year interaction is negative, the

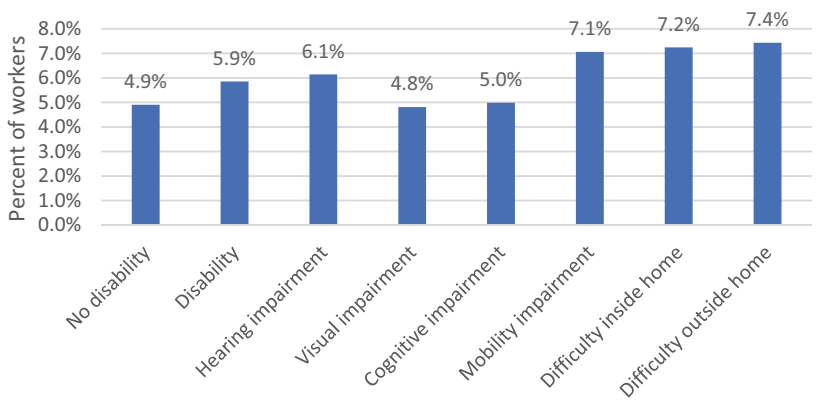

Fig. 1 Work primarily at home by disability status, 2009-2018 
Table 2 Work primarily at home by disability status, 2009-2018

Figures reflect percent who primarily work at home (from American Community Survey)

$\begin{array}{llllll}\text { All workers } & \text { Employees } & & \text { Self-employed } & \\ \text { No disability } & \text { Disability } & \text { No disability } \quad \text { Disability } & \text { No disability } \quad \text { Disability }\end{array}$

(1)

(2)

(3)

(4)

(5)

(6)

All

$4.6 \%$

$5.7 \% * *$

$2.8 \%$

$3.3 \% * *$

$21.3 \%$

$23.1 \% * *$

Female

Male

$4.8 \%$

$4.4 \%$

$6.0 \% * *$

$3.0 \%$

$5.4 \% * *$

$2.6 \%$

$3.6 \% * *$

$27.7 \%$

$29.9 \% * *$

Race and ethnicity

White non-Hispanic

$5.3 \%$

Black

Hispanic

Other

Age

18-34

$35-49$

50-64

65 plus

Education

No HS

Some HS, no degree

HS degree

Some college

Associate's

Bachelor's

Master's

Professional degree

Ph.D

Live alone

Yes

No

Live with children under age 18

Yes

No

Live with elders age 65 or older

Yes

No

Live in house with Internet access

Yes

No

$\mathrm{N}$

$2.8 \%$

$3.0 \%$

$4.1 \%$

$2.8 \%$

$4.9 \%$

$5.7 \%$

$9.5 \%$

\section{$3.3 \%$}

$2.7 \%$

$3.2 \%$

$4.2 \%$

$4.1 \%$

$6.6 \%$

$6.4 \%$

$5.0 \%$

$6.2 \%$

$4.5 \%$

$5.3 \%$

$4.7 \%$

$4.4 \%$

$4.4 \%$

$6.0 \%$

$5.0 \%$

$4.2 \%$

$13,019,338$
$6.3 \% * *$

$3.6 \% * *$

$4.1 \% * *$

$5.4 \% * *$

$3.2 \% * *$

$4.8 \%$

$5.7 \%$

$10.4 \% * *$

$3.2 \%$

$1.8 \%$

$1.8 \%$

$2.9 \%$

$2.0 \%$

$3.1 \%$

$3.3 \%$

$4.7 \%$

$4.8 \% * *$

$4.4 \% * *$

$4.2 \%$ **

$5.6 \% * *$

$5.1 \% * *$

$8.4 \% * *$

$8.6 \% * *$

$9.8 \% * *$

$11.8 \%$ **

$1.8 \%$

$1.6 \%$

$1.7 \%$

$2.6 \%$

$2.5 \%$

$4.2 \%$

$4.3 \%$

$3.0 \%$

$4.1 \%$

$5.6 \% * *$

$6.1 \% * *$

$2.7 \%$

$3.5 \%$

$6.1 \% * *$

$4.6 \% * *$

$2.8 \%$

$2.7 \%$

$5.1 \% * *$

$8.5 \%$ **

$2.7 \%$

$3.4 \%$

$6.1 \% * *$

$5.3 \% * *$

810,897
$3.2 \%$

$2.5 \%$

$11,669,172$
$2.9 \% * *$

$17.7 \%$

$19.6 \%$ **

$3.5 \% * *$

$2.4 \% * *$

$23.0 \%$

$21.1 \%$

$15.4 \%$

$16.4 \%$

$20.1 \%$

$20.5 \%$

$21.3 \%$

$26.2 \%$

$24.4 \% * *$

$21.1 \% * *$

$17.6 \% * *$

$19.4 \% * *$

$20.4 \%$

$21.2 \%$

$22.3 \%$ **

$26.4 \%$

$5.4 \% * *$

$3.0 \% * *$

$2.6 \% * *$

$2.3 \% * *$

$3.2 \% * *$

$3.1 \% * *$

$4.9 \% * *$

$5.0 \% * *$

$4.9 \% * *$

$13.3 \%$

$16.1 \% * *$

$17.3 \% * *$

$19.7 \% * *$

$17.2 \%$

$24.1 \%$ **

$23.5 \%$

$30.0 \%$ **

$32.8 \% *$

$19.8 \%$ **

$7.5 \%$ **

$11.7 \%$

$28.7 \%$ **

$23.0 \% * *$

$24.0 \% * *$

$3.7 \% * * \quad 22.7 \%$

$21.7 \%$

$23.5 \%$ **

$21.9 \% * *$

$2.8 \% \quad 20.7 \%$

$20.9 \%$

$22.3 \% * *$

$25.9 \% * *$

$4.7 \% * * \quad 23.9 \%$

$24.2 \% * *$

$22.3 \% * *$

104,606

* Significant difference by disability status at $\mathrm{p}<0.05$

$* * \mathrm{p}<0.01$

overall predicted trend for workers with disabilities remains positive when the interaction and main effects are added.

\section{Any Work at Home}

While the ACS results clearly indicate that workers with disabilities are more likely to work primarily at home, this may not apply to doing "any work" at home. The results from 
Table 3 Work primarily at home by disability and occupation, 2009-2018

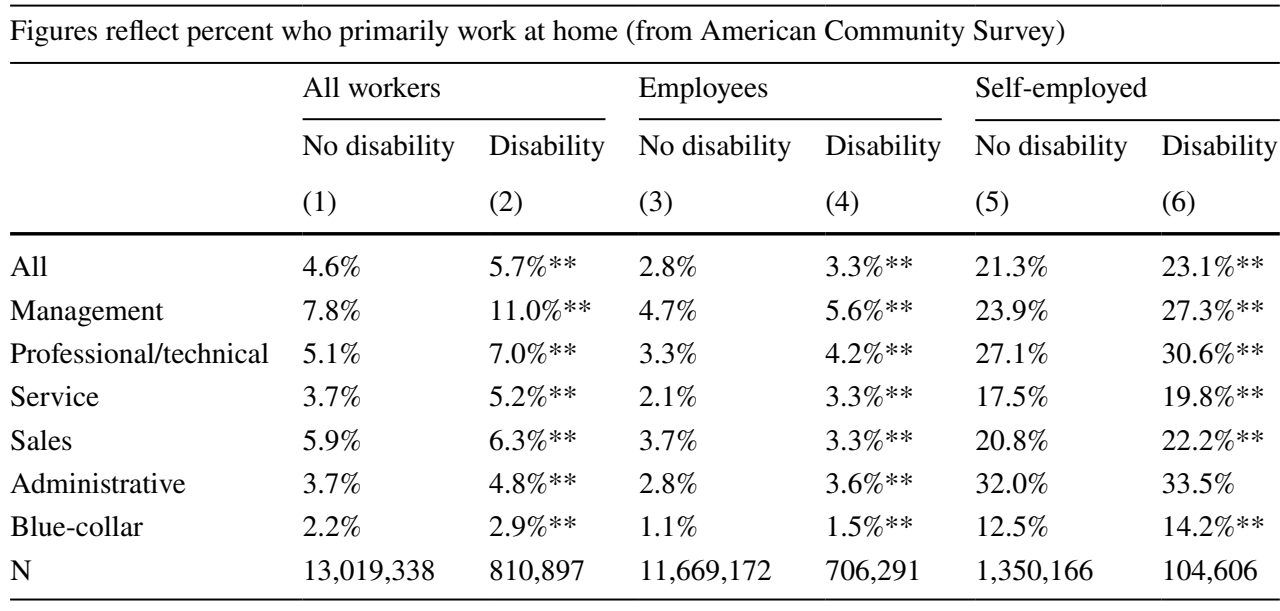

*Significant difference by disability status at $\mathrm{p}<0.05$

$* * \mathrm{p}<0.01$ the ATUS in Table 5 indicate that this is the case. Asked about all their activities during a reference day, $22.7 \%$ of the employed respondents with disabilities said they performed any paid work at home during the day, which is not significantly greater than the $21.7 \%$ of employed respondents without disabilities who gave the same response.

Broken down by disability type, the only significant disability gap in any home-based work occurred for workers with mobility impairments, of whom $26.4 \%$ reported any home-based work compared to $21.7 \%$ of workers without disabilities. Broken down by broad occupation, the only significant disability gap occurred in management occupations (columns 1 and 2), but this significant difference disappears when examining employees and self-employed separately (columns 3 to 6). So the overall gap may reflect the increased likelihood of workers with disabilities to be self-employed (where the rate of home-based work is higher in general). The disability differences, both among employees and the self-employed, remain statistically insignificant in regressions that control for demographic characteristics and occupation (not reported but available).

The story is slightly different in analyzing the larger sample in the combined CPS Disability Supplements done in 2012 and 2019. While the simple comparisons in Table 6 indicate that workers with disabilities are more likely to primarily work at home, the regressions in Table 7 (columns 1 to 3 ) find that this difference is no longer statistically significant when controlling for demographic characteristics and occupation.

In contrast to the ATUS results, however, both simple comparisons and regressions show that workers with disabilities are more likely than those without disabilities to do any work at home (Table 6, columns 1 and 2, and Table 7, columns 4 to 6). The regressions also show that employees with disabilities are more likely to be paid for work at home and have a formal arrangement with their employer (Table 7, columns 7 and 8). Work at home appeared to increase for employees in general from 2012 to 2019 (columns 2, 5, 7, and 8 of Table 7, consistent with the positive time trend from ACS data in Table 4), but the insignificant interactions with disability status do not point to different trends for workers with and without disabilities.

Examining the reasons workers offered for working at home, Table 6 shows that workers with disabilities were less likely to cite reduced commuting and coordination of work and family needs, and more likely to cite illness, disability, or health reasons.

Therefore, the ATUS and CPS results give a somewhat mixed message on disability differences in working at home. While the ATUS results do not show significant differences by disability status in doing any work at home (either in simple comparisons or regressions), the CPS regression results point to a significantly higher likelihood of work at home for both employees and self-employed workers, and a higher likelihood of paid work and a formal arrangement for employees with disabilities compared to those without disabilities. We put a somewhat heavier weight on the CPS results, given the larger sample size and the additional measures related to work at home. Also, as noted in the data section, there is at least a five-month lag between the disability measure and the work at home measure for the ATUS data, making the disability measure less reliable in the ATUS data.

\section{Wages of Home-Based Workers}

How does working at home affect the wages of workers with and without disabilities? Table 8 reports on wage regressions with standard controls that include detailed occupation. As shown at the bottom of the table, the disability pay gap is 
Table 4 Predicting work primarily at home

Dep. var. $=$ primarily work at home (from American Community Survey)

All workers

(1)

$0.006^{* *}$

(0.000)

Vision

Hearing

Cognitive

Mobility

Self-care

Outside home

Year

Disability*year

Demographics

Female

White non-Hispanic (excl.)

Black

Hispanic

Other

Age 18-34 (excl.)

Age 35-49

Age 50-64

Age 65 plus

Live alone

Live with children under age 18

Live with elders over age 65

Education dummies

Occupation dummies

$\mathrm{n}$

R-squared

$.00113^{* * *}$

(0.00002)

$0.002 * *$

(0.000)

$-0.020^{* *}$

(0.000)

$-0.012^{* *}$

(0.000)

$-0.012 * *$

(0.000)

(0.000)

$0.026^{* *}$

(0.000)

$0.059^{* *}$

(0.000)

$0.009 * *$

(0.000)

$0.006^{* *}$

(0.000)

$0.009 * *$

(0.000)

Yes

Yes

$13,334,984$

0.017
(2)
Employees

(3)

$0.008 * *$

$-0.004^{* *}$

$(0.001)$

$-0.002^{* *}$

(0.001)

0.001

(0.001)

0.008 **

$(0.001)$

0.002

$(0.001)$

$0.022 * *$

$(0.001)$

$.00113^{* *}$

(0.00002)

(0.001)

$(0.00003)$

$-0.00051^{* *}$

(0.00012)

$0.001 * *$

(0.000)

$0.002 * *$

(0.000)

$-0.020^{* *}$

(0.000)

$-0.012^{* *}$

(0.000)

$-0.012^{* *}$

(0.000)

$-0.020^{* *}$

(0.000)

$-0.012^{* *}$

(0.000)

$-0.012^{* *}$

$(0.000)$

$0.017 * *$

(0.000)
$0.026^{* *}$

(0.000)

0.059 **

(0.000)

$0.009^{* *}$

$(0.000)$

$0.006^{* * *}$

(0.000)

$0.009^{* *}$

(0.000)

Yes

Yes

$13,334,984$

0.017
$0.017 * *$

$(0.000)$

$0.026^{* *}$

(0.000)

$0.059^{* * *}$

$(0.000)$

$0.009^{* *}$

$(0.000)$

$0.006^{* * *}$

$(0.000)$

$0.009^{* *}$

(0.000)

Yes

Yes

13,334,984

0.017
(4)

$0.004 * *$

(0.000)

.

$\begin{array}{ll} & -0.001^{*} \\ & (0.001) \\ & -0.003^{* *} \\ & (0.000) \\ & 0.001 \\ & (0.001) \\ & 0.006^{* *} \\ & (0.001) \\ & 0.003^{*} \\ & (0.001) \\ & 0.015^{* *} \\ & (0.001) \\ & .00130^{* *} \\ & (0.00002) \\ & \end{array}$

(5)

(6)

$0.005 * *$

(0.001)

$-0.001^{*}$
$(0.001)$
$-0.003^{* *}$
$(0.000)$
0.001
$(0.001)$
$0.006^{* *}$
$(0.001)$
$0.003^{*}$
$(0.001)$
$0.015^{* *}$
$(0.001)$
$.00130^{* *}$
$(0.00002)$

.00131 **

(0.00002)

$-0.00028^{* *}$

(0.00010)

0.000

(0.000)

$-0.000$

0.000

$(0.000)$

$-0.011^{* *}$
$(0.000)$
$-0.007 * *$
$(0.000)$
$-0.004^{* *}$
$(0.000)$

$-0.011^{* *}$

$-0.011^{* *}$

(0.000)

$(0.000)$

$-0.007^{* *}$

$-0.007^{* *}$

$(0.000)$

$(0.000)$

$-0.004 * *$

$-0.004 * *$

$(0.000)$

\section{$0.008 * *$}

$(0.000)$

$0.011 * *$

$(0.000)$

$0.021 * *$

(0.000)

0.011 **

$(0.000)$

$0.004 * *$

$(0.000)$

$0.007^{* * *}$

(0.000)

Yes

Yes

11,930,178

0.010

(0.000)

$0.008 * *$

(0.000)

0.011 **

(0.000)

0.021 **

(0.000)

0.011 **

$(0.000)$

$0.004 * *$

$(0.000)$

$0.007^{* * *}$

(0.000)

Yes

Yes

$11,930,178$

0.010

Robust standard errors in parentheses

$* \mathrm{p}<0.05$

$* * \mathrm{p}<0.01$ 


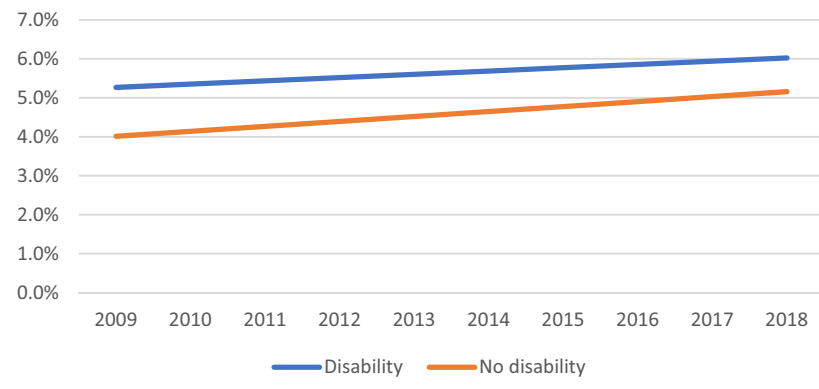

Fig. 2 Telework by disability status, 2009-2018

slightly larger among homeworkers (-13.5\%) than among non-homeworkers $(-10.4 \%)$ (column 1$)$, with similar gaps when looking just at employees or self-employed workers (columns 2 and 3). While the differences in these disability gaps between homeworkers and non-homeworkers are small, they are statistically significant. ${ }^{2}$

Along with comparing workers with and without disabilities, another interesting comparison is between homeworkers and non-homeworkers. Table 8 shows that employees without disabilities earn slightly more on average $(3.7 \%)$ if they work primarily at home, while the difference for employees with disabilities is not significant. In contrast, self-employed workers earn less by working at home, with home work gaps of $8.1 \%$ among workers without disabilities and $8.6 \%$ among those with disabilities (each of these gaps is statistically significant by itself, but the difference between these gaps is not significant).

The principal implication from these results is that the pay gaps faced by workers with disabilities are not substantially altered by working at home: they continue to earn less than workers without disabilities when working at home. Therefore, the potential benefit of increased home-based work for people with disabilities would appear to lie in greater employment opportunities, not increased pay.

\section{Potential for Jobs to be Done at Home}

The analysis of current patterns in home-based work begs the question of what jobs can potentially be done at home. The expansion of computer and information technologies enables more and more jobs to be done remotely. In a 2020 study, Dingel and Neiman studied which jobs could potentially be done entirely at home, using data on occupational characteristics from the federal $\mathrm{O} *$ Net database [43]. They

\footnotetext{
2 The differences in the disability gaps between homeworkers and non-homeworkers are all significant at $\mathrm{p}<.001$, while the differences in the homeworking gaps between workers with and without disabilities are significant at $\mathrm{p}<.001$ for all workers and employees, but not for self-employed workers.
}

assign a potential to each occupational category, the category designated with a two-digit number, and then present a score for each category reflecting how many jobs within that category could be done entirely at home. Those scores are replicated in column 1 of Table 9. The actual number of workers working primarily at home in the 2014-2018 period (using ACS) is shown in column 2. The numbers of actual home-based workers in each category (column 2) are uniformly lower than the number of potential home-based workers (column 1), illustrating substantial room for expansion of home-based work in each occupational category. There is a strong positive correlation of 0.59 between the two measures, as shown at the bottom of Table 9, providing some validation for Dingel and Neiman's measures of which occupations are more amenable to work at home.

How much potential is there for workers with disabilities to work primarily at home? Column 3 of Table 9 shows the number of workers with disabilities in each of the two-digit occupational categories. People with disabilities appear to have less potential for expanding telework in their current jobs: the distribution of workers with disabilities has a strong negative correlation of -0.68 with the potential for jobs to be done entirely at home, as shown at the bottom of Table 9 . This negative relationship is also demonstrated by estimating the percent of jobs that could be done entirely at home, using current occupational distributions of workers with and without disabilities. Based on their current occupational distributions, Table 9 shows that close to two in five (39.5\%) of the jobs held by workers without disabilities could be done entirely at home, compared to only one-third (34.0\%) of the jobs held by workers with disabilities.

In sum, while workers with disabilities are more likely to be working from home currently, their current jobs offer less potential for substantially expanding the extent to which they could work primarily at home. This reflects their disproportionately greater likelihood of being in service and bluecollar occupations that are less amenable to home-based work (e.g., buildings and grounds cleaning and maintenance, where workers with disabilities have the greatest representation). It is also possible that the nature and severity of their disabilities are more likely to limit them to those occupations that cannot be done from home.

\section{Discussion}

These results strongly point to the value that work at home has for many people with disabilities. While people with disabilities face various barriers in obtaining jobs, these barriers are most likely to limit their access to professional and other white-collar jobs where home-based work is often more feasible and productive; as seen in Table 9, they are more likely to be in lower-paying blue-collar and service 
Table 5 Any work at home by disability status, 2008-2018

\begin{tabular}{|c|c|c|c|c|c|c|}
\hline & \multicolumn{2}{|l|}{ All workers } & \multicolumn{2}{|l|}{ Employees } & \multicolumn{2}{|l|}{ Self-employed } \\
\hline & $\begin{array}{l}\text { No disability } \\
\text { (1) }\end{array}$ & $\begin{array}{l}\text { Disability } \\
\text { (2) }\end{array}$ & $\begin{array}{l}\text { No disability } \\
\text { (3) }\end{array}$ & $\begin{array}{l}\text { Disability } \\
\text { (4) }\end{array}$ & $\begin{array}{l}\text { No disability } \\
\text { (5) }\end{array}$ & $\begin{array}{l}\text { Disability } \\
\text { (6) }\end{array}$ \\
\hline All & $21.7 \%$ & $22.7 \%$ & $17.9 \%$ & $15.9 \%$ & $52.7 \%$ & $57.9 \%$ \\
\hline Hearing impairment & & $22.3 \%$ & & $15.3 \%$ & & $58.8 \%$ \\
\hline Vision impairment & & $19.6 \%$ & & $15.2 \%$ & & $49.6 \%$ \\
\hline Cognitive impairment & & $20.5 \%$ & & $14.4 \%$ & & $48.8 \%$ \\
\hline Mobility impairment & & $26.4 \% *$ & & $17.6 \%$ & & $68.9 \% *$ \\
\hline Difficulty with self-care & & $24.0 \%$ & & $15.6 \%$ & & $61.4 \%$ \\
\hline Difficulty outside home & & $24.0 \%$ & & $15.4 \%$ & & $56.8 \%$ \\
\hline \multicolumn{7}{|l|}{ Occupation } \\
\hline Management & $33.3 \%$ & $46.7 \% *$ & $27.1 \%$ & $33.5 \%$ & $56.5 \%$ & $67.3 \%$ \\
\hline Management-related & $27.7 \%$ & $19.4 \%$ & $23.3 \%$ & $13.4 \%$ & $67.0 \%$ & $41.4 \%$ \\
\hline Professional/technical & $33.8 \%$ & $31.9 \%$ & $30.5 \%$ & $28.2 \%$ & $68.9 \%$ & $65.2 \%$ \\
\hline Service & $11.4 \%$ & $9.0 \%$ & $8.1 \%$ & $6.2 \%$ & $44.5 \%$ & $38.4 \%$ \\
\hline Sales & $23.5 \%$ & $31.2 \%$ & $18.8 \%$ & $19.7 \%$ & $48.7 \%$ & $70.1 \% *$ \\
\hline Administrative & $10.9 \%$ & $10.6 \%$ & $9.2 \%$ & $6.4 \%$ & $58.3 \%$ & $94.5 \% *$ \\
\hline Blue-collar & $9.1 \%$ & $9.8 \%$ & $6.6 \%$ & $7.7 \%$ & $32.0 \%$ & $27.3 \%$ \\
\hline $\mathrm{n}$ & 39,380 & 1,413 & 34,567 & 1,154 & 4,813 & 259 \\
\hline
\end{tabular}

*Significant difference from non-disability sample at $\mathrm{p}<0.05$

$* * \mathrm{p}<0.01$

Table 6 Type and reasons for work at home by disability status, 2012 and 2019

Based on Current Population Survey disability supplements in May 2012 and July 2019. Limited to employed workers

\begin{tabular}{|c|c|c|c|c|c|c|}
\hline & \multicolumn{2}{|l|}{ All workers } & \multicolumn{2}{|l|}{ Employees } & \multicolumn{2}{|l|}{ Self-employed } \\
\hline & $\begin{array}{l}\text { No disability } \\
\text { (1) }\end{array}$ & $\begin{array}{l}\text { Disability } \\
\text { (2) }\end{array}$ & $\begin{array}{l}\text { No disability } \\
\text { (3) }\end{array}$ & $\begin{array}{l}\text { Disability } \\
\text { (4) }\end{array}$ & $\begin{array}{l}\text { No disability } \\
\text { (5) }\end{array}$ & $\begin{array}{l}\text { Disability } \\
\text { (6) }\end{array}$ \\
\hline Typically work at home & $4.7 \%$ & $7.9 \% *$ & $2.7 \%$ & $3.5 \%$ & $22.8 \%$ & $33.1 \% *$ \\
\hline Any work at home & $23.0 \%$ & $26.3 \% *$ & $19.1 \%$ & $18.7 \%$ & $58.8 \%$ & $69.9 \% *$ \\
\hline Hearing impairment & & $29.5 \%$ & & $19.8 \%$ & & $73.0 \% *$ \\
\hline Vision impairment & & $22.3 \%$ & & $15.8 \%$ & & $64.4 \%$ \\
\hline Cognitive impairment & & $21.3 \%$ & & $15.8 \%$ & & $65.4 \%$ \\
\hline Mobility impairment & & $27.0 \% *$ & & $18.7 \%$ & & $67.8 \%$ \\
\hline Difficulty with self-care & & $37.2 \% *$ & & $20.9 \%$ & & $81.3 \% *$ \\
\hline Difficulty outside home & & $27.4 \%$ & & $20.9 \%$ & & $63.0 \%$ \\
\hline Paid for work at home & $14.1 \%$ & $13.6 \%$ & $14.1 \%$ & $13.6 \%$ & na & $\mathrm{Na}$ \\
\hline Formal arrangement with employer to work at home & $10.8 \%$ & $11.7 \%$ & $10.8 \%$ & $11.7 \%$ & na & $\mathrm{Na}$ \\
\hline \multicolumn{7}{|l|}{ If work at home, reasons for doing so } \\
\hline Less commuting & $14.0 \%$ & $9.5 \% *$ & $15.9 \%$ & $11.6 \%$ & $8.2 \%$ & $6.3 \%$ \\
\hline Reduced expenses for transportation, food, etc & $5.1 \%$ & $5.5 \%$ & $5.2 \%$ & $6.0 \%$ & $4.7 \%$ & $4.8 \%$ \\
\hline Coordinate work and family needs & $15.9 \%$ & $11.0 \% *$ & $17.8 \%$ & $13.1 \%$ & $10.3 \%$ & $7.7 \%$ \\
\hline More control over life & $12.6 \%$ & $8.9 \% *$ & $13.3 \%$ & $10.4 \%$ & $10.4 \%$ & $6.7 \%$ \\
\hline Illness, disability, health & $1.7 \%$ & $9.6 \% *$ & $2.1 \%$ & $10.0 \% *$ & $0.7 \%$ & $9.0 \% *$ \\
\hline Mandated to reduce employer costs & $3.9 \%$ & $4.7 \%$ & $5.1 \%$ & $6.9 \%$ & $0.6 \%$ & $1.2 \%$ \\
\hline Mandated for trans. mgt. or pollution reqs & $1.0 \%$ & $0.7 \%$ & $1.2 \%$ & $1.1 \%$ & $0.2 \%$ & $0.0 \% *$ \\
\hline More productive & $27.1 \%$ & $23.3 \%$ & $31.9 \%$ & $31.4 \%$ & $12.9 \%$ & $10.8 \%$ \\
\hline Business at home & $21.2 \%$ & $35.1 \%$ & $6.4 \%$ & $13.7 \% *$ & $65.1 \%$ & $67.9 \%$ \\
\hline Other & $22.2 \%$ & $21.6 \%$ & $26.2 \%$ & $28.8 \%$ & $10.4 \%$ & $10.5 \%$ \\
\hline $\mathrm{n}$ & 93,281 & 3,896 & 83,152 & 10,129 & 3,239 & 657 \\
\hline
\end{tabular}

*Significant difference from non-disability sample at $\mathrm{p}<0.05$

$* * \mathrm{p}<.0 .01$ 
Table 7 Predicting work at home with CPS supplement

\begin{tabular}{|c|c|c|c|c|c|c|c|c|}
\hline & \multicolumn{3}{|c|}{ Primarily work at home } & \multicolumn{3}{|c|}{ Any work at home } & \multirow{2}{*}{$\begin{array}{l}\text { Paid for work at } \\
\text { home } \\
\text { Employees } \\
\text { (7) }\end{array}$} & \multirow{2}{*}{$\begin{array}{l}\text { Formal arrange- } \\
\text { ment to work at } \\
\text { home } \\
\text { Employees } \\
\text { (8) }\end{array}$} \\
\hline & $\begin{array}{l}\text { All workers } \\
\text { (1) }\end{array}$ & $\begin{array}{l}\text { Employees } \\
\text { (2) }\end{array}$ & $\begin{array}{l}\text { Self-employed } \\
\text { (3) }\end{array}$ & $\begin{array}{l}\text { All workers } \\
\text { (4) }\end{array}$ & $\begin{array}{l}\text { Employees } \\
\text { (5) }\end{array}$ & $\begin{array}{l}\text { Self-employed } \\
\text { (6) }\end{array}$ & & \\
\hline Disability & $\begin{array}{l}0.009 \\
(0.006)\end{array}$ & $\begin{array}{l}0.002 \\
(0.004)\end{array}$ & $\begin{array}{l}0.020 \\
(0.028)\end{array}$ & $\begin{array}{l}0.048^{* *} \\
(0.010)\end{array}$ & $\begin{array}{l}0.032 * * \\
(0.009)\end{array}$ & $\begin{array}{l}0.104 * * \\
(0.030)\end{array}$ & $\begin{array}{l}0.023 * * \\
(0.008)\end{array}$ & $\begin{array}{l}0.020^{* *} \\
(0.007)\end{array}$ \\
\hline $\begin{array}{l}\text { Disability } *(2019 \\
\text { year dummy) }\end{array}$ & $\begin{array}{l}0.008 \\
(0.009)\end{array}$ & $\begin{array}{l}0.004 \\
(0.006)\end{array}$ & $\begin{array}{l}0.026 \\
(0.040)\end{array}$ & $\begin{array}{l}-0.008 \\
(0.014)\end{array}$ & $\begin{array}{l}-0.004 \\
(0.013)\end{array}$ & $\begin{array}{l}-0.038 \\
(0.043)\end{array}$ & $\begin{array}{l}-0.005 \\
(0.012)\end{array}$ & $\begin{array}{l}0.005 \\
(0.011)\end{array}$ \\
\hline 2019 year dummy & $\begin{array}{l}0.007 * * \\
(0.001)\end{array}$ & $\begin{array}{l}0.009 * * \\
(0.001)\end{array}$ & $\begin{array}{l}0.005 \\
(0.009)\end{array}$ & $\begin{array}{l}0.020 * * \\
(0.003)\end{array}$ & $\begin{array}{l}0.024 * * \\
(0.003)\end{array}$ & $\begin{array}{l}0.016 \\
(0.011)\end{array}$ & $\begin{array}{l}0.039 * * \\
(0.002)\end{array}$ & $\begin{array}{l}0.035 * * \\
(0.002)\end{array}$ \\
\hline Female & $\begin{array}{l}0.018 * * \\
(0.003)\end{array}$ & $\begin{array}{l}0.009 * * \\
(0.003)\end{array}$ & $\begin{array}{l}0.103 * * \\
(0.018)\end{array}$ & $\begin{array}{l}0.006 \\
(0.005)\end{array}$ & $\begin{array}{l}0.002 \\
(0.005)\end{array}$ & $\begin{array}{l}0.085 * * \\
(0.018)\end{array}$ & $\begin{array}{l}0.007 \\
(0.005)\end{array}$ & $\begin{array}{l}0.016 * * \\
(0.004)\end{array}$ \\
\hline Age & $\begin{array}{l}-0.000 \\
(0.001)\end{array}$ & $\begin{array}{l}0.001 \\
(0.000)\end{array}$ & $\begin{array}{l}-0.000 \\
(0.003)\end{array}$ & $\begin{array}{l}0.007 * * \\
(0.001)\end{array}$ & $\begin{array}{l}0.007 * * \\
(0.001)\end{array}$ & $\begin{array}{l}0.005 \\
(0.003)\end{array}$ & $\begin{array}{l}0.005 * * \\
(0.001)\end{array}$ & $\begin{array}{l}0.004 * * \\
(0.001)\end{array}$ \\
\hline Age squared & $\begin{array}{l}0.000 * * \\
(0.000)\end{array}$ & $\begin{array}{l}-0.000 \\
(0.000)\end{array}$ & $\begin{array}{l}0.000 \\
(0.000)\end{array}$ & $\begin{array}{l}-0.000^{* *} \\
(0.000)\end{array}$ & $\begin{array}{l}-0.000^{* *} \\
(0.000)\end{array}$ & $\begin{array}{l}-0.000 \\
(0.000)\end{array}$ & $\begin{array}{l}-0.000 * * \\
(0.000)\end{array}$ & $\begin{array}{l}-0.000 * * \\
(0.000)\end{array}$ \\
\hline $\begin{array}{l}\text { Race } \\
\text { White non-His- } \\
\text { panic (excl.) }\end{array}$ & & & & & & & & \\
\hline Black & $\begin{array}{l}-0.015^{* *} \\
(0.003)\end{array}$ & $\begin{array}{l}-0.010^{* *} \\
(0.003)\end{array}$ & $\begin{array}{l}-0.014 \\
(0.028)\end{array}$ & $\begin{array}{l}-0.059 * * \\
(0.006)\end{array}$ & $\begin{array}{l}-0.053^{* *} \\
(0.006)\end{array}$ & $\begin{array}{l}-0.031 \\
(0.031)\end{array}$ & $\begin{array}{l}-0.042^{* *} \\
(0.006)\end{array}$ & $\begin{array}{l}-0.031^{* *} \\
(0.005)\end{array}$ \\
\hline Hispanic & $\begin{array}{l}-0.010^{* *} \\
(0.003)\end{array}$ & $\begin{array}{l}-0.008^{* *} \\
(0.002)\end{array}$ & $\begin{array}{l}-0.013 \\
(0.020)\end{array}$ & $\begin{array}{l}-0.040^{* *} \\
(0.005)\end{array}$ & $\begin{array}{l}-0.032 * * \\
(0.005)\end{array}$ & $\begin{array}{l}-0.075^{* *} \\
(0.026)\end{array}$ & $\begin{array}{l}-0.031 * * \\
(0.005)\end{array}$ & $\begin{array}{l}-0.021 * * \\
(0.004)\end{array}$ \\
\hline Other & $\begin{array}{l}-0.010^{*} \\
(0.004)\end{array}$ & $\begin{array}{l}-0.010^{* *} \\
(0.003)\end{array}$ & $\begin{array}{l}0.032 \\
(0.026)\end{array}$ & $\begin{array}{l}-0.052^{* *} \\
(0.008)\end{array}$ & $\begin{array}{l}-0.045^{* *} \\
(0.008)\end{array}$ & $\begin{array}{l}-0.078^{* *} \\
(0.030)\end{array}$ & $\begin{array}{l}-0.036^{* *} \\
(0.007)\end{array}$ & $\begin{array}{l}-0.027^{* *} \\
(0.006)\end{array}$ \\
\hline $\begin{array}{l}\text { Education } \\
\text { No HS degree } \\
\quad \text { (excl.) }\end{array}$ & & & & & & & & \\
\hline HS degree & $\begin{array}{l}0.002 \\
(0.003)\end{array}$ & $\begin{array}{l}-0.005 \\
(0.003)\end{array}$ & $\begin{array}{l}0.073 * * \\
(0.021)\end{array}$ & $\begin{array}{l}-0.001 \\
(0.006)\end{array}$ & $\begin{array}{l}-0.008 \\
(0.005)\end{array}$ & $\begin{array}{l}0.091 * * \\
(0.033)\end{array}$ & $\begin{array}{l}-0.010^{*} \\
(0.004)\end{array}$ & $\begin{array}{l}-0.007 \\
(0.004)\end{array}$ \\
\hline Some college & $\begin{array}{l}0.012 * * \\
(0.004)\end{array}$ & $\begin{array}{l}-0.002 \\
(0.003)\end{array}$ & $\begin{array}{l}0.105 * * \\
(0.025)\end{array}$ & $\begin{array}{l}0.042^{* *} \\
(0.007)\end{array}$ & $\begin{array}{l}0.022 * * \\
(0.006)\end{array}$ & $\begin{array}{l}0.199 * * \\
(0.036)\end{array}$ & $\begin{array}{l}0.013 * \\
(0.005)\end{array}$ & $\begin{array}{l}0.014 * * \\
(0.005)\end{array}$ \\
\hline Associate's degree & $\begin{array}{l}0.011^{*} \\
(0.005)\end{array}$ & $\begin{array}{l}-0.003 \\
(0.004)\end{array}$ & $\begin{array}{l}0.120 * * \\
(0.027)\end{array}$ & $\begin{array}{l}0.044 * * \\
(0.008)\end{array}$ & $\begin{array}{l}0.029 * * \\
(0.007)\end{array}$ & $\begin{array}{l}0.192 * * \\
(0.039)\end{array}$ & $\begin{array}{l}0.018 * * \\
(0.006)\end{array}$ & $\begin{array}{l}0.019 * * \\
(0.006)\end{array}$ \\
\hline Bachelor's degree & $\begin{array}{l}0.024 * * \\
(0.005)\end{array}$ & $\begin{array}{l}0.005 \\
(0.004)\end{array}$ & $\begin{array}{l}0.147 * * \\
(0.025)\end{array}$ & $\begin{array}{l}0.116^{* *} \\
(0.008)\end{array}$ & $\begin{array}{l}0.099 * * \\
(0.008)\end{array}$ & $\begin{array}{l}0.229 * * \\
(0.036)\end{array}$ & $\begin{array}{l}0.081 * * \\
(0.007)\end{array}$ & $\begin{array}{l}0.057 * * \\
(0.006)\end{array}$ \\
\hline Graduate degree & $\begin{array}{l}0.031 * * \\
(0.006)\end{array}$ & $\begin{array}{l}0.008 \\
(0.005)\end{array}$ & $\begin{array}{l}0.178 * * \\
(0.032)\end{array}$ & $\begin{array}{l}0.192 * * \\
(0.011)\end{array}$ & $\begin{array}{l}0.181 * * \\
(0.011)\end{array}$ & $\begin{array}{l}0.243 * * \\
(0.040)\end{array}$ & $\begin{array}{l}0.125 * * \\
(0.010)\end{array}$ & $\begin{array}{l}0.089 * * \\
(0.009)\end{array}$ \\
\hline $\begin{array}{l}\text { Occupation dum- } \\
\text { mies }\end{array}$ & Yes & Yes & Yes & Yes & Yes & Yes & Yes & Yes \\
\hline $\mathrm{N}$ & 97,177 & 86,391 & 10,786 & 97,177 & 86,391 & 10,786 & 86,391 & 86,391 \\
\hline R-squared & 0.104 & 0.059 & 0.257 & 0.255 & 0.247 & 0.280 & 0.197 & 0.151 \\
\hline
\end{tabular}

Robust standard errors in parentheses

$* \mathrm{p}<0.05$

$* * \mathrm{p}<0.01$ 
Table 8 Predicting wages of those working primarily at home
Dependent variable $=\ln$ (hourly pay). Based on 2009-2018 ACS data for those working 50-52 weeks last year

Sample

All workers

Employees

Self-employed

(1)

(2)

(3)

No disability, non-homeworker (excluded)

No disability, homeworker

$-0.067^{*}$

$0.036^{* *}$

$-0.084 * *$

Disability, non-homeworker

(0.012)

(0.014)

(0.006)

Disability, homeworker

$-0.11 * *$

$-0.11 * *$

$-0.122 * *$

(0.003)

$-0.212 * *$

(0.003)

(0.003)

Observations

(0.011)

$-0.132 * *$

$-0.212 * *$

Observatio

$11,294,676$

(0.013)

(0.011)

R-squared

0.441

$10,177,511$

$1,117,165$

Estimated disability pay gap for

Non-homeworkers

$-10.4 \% * *$

0.489

0.262

Homeworkers

$-13.5 \% * *$

$-10.4 \% * *$

$-11.5 \% * *$

Estimated homework pay gap for

Workers without disabilities

$-6.5 \% * *$

$-15.5 \% * *$

$-12.0 \% * *$

Workers with disabilities

$-9.7 \% * *$

$3.7 \% * *$

$-8.1 \% * *$

$-8.6 \% * *$

All regressions include controls for gender, race/ethnicity (3 dummies), education ( 8 dummies), labor market experience both linear and squared, state (50 dummies), occupation (481 dummies), and year ( 9 dummies)

Robust standard errors in parentheses

$* \mathrm{p}<0.05$

$* * \mathrm{p}<0.01$

jobs where home-based work is generally less feasible. In addition, self-employed workers have more choice about where to work than do employees (who must obtain an employer's permission), so the higher rate of home-based work among self-employed workers with disabilities likely indicates the advantages of home-based work [44].

At least some of the employment barriers faced by workers with disabilities may be lessened by working from home. Employers may be more willing to hire workers with disabilities for home-based positions due to lower concern about workplace accommodations and attitudes of supervisors and co-workers; discomfort may be lessened by remote interaction. The possibility of home-based work does not excuse employers from creating more welcoming and accessible workplaces. But it is nevertheless possible that home-based work may cause employers to take a closer look at what workers with disabilities can do rather than at how they fit into a traditional workplace.

In line with these benefits, pay levels and raises for homebased workers may be determined more by actual job performance than irrelevant stereotypes and office dynamics that can disadvantage workers with disabilities. However, our results show that the disability wage gap is just as large, and possibly larger, among home-based workers than among on-site employees. This indicates that while increased availability of home-based work may improve employment opportunities for workers with disabilities, it is unlikely to erase wage disparities without other interventions.

Working from home can be a reasonable accommodation under the Americans with Disabilities Act [45], but some employers are resistant to ADA requirements and small employers are not covered by the law [46]. Some people with disabilities are frustrated that employers are suddenly so willing to accommodate workers without disabilities during the COVID pandemic after resisting disability accommodations for so long [47, 48]. Almost all workers (with and without disabilities) receive accommodations to meet their personal needs, even simple items such as having an employer-provided chair in which to sit. By shaking up the structure of work, the crisis may spur employers' and employees' creativity in devising new ways to meet employees' needs, both at home and in the worksite.

The types of jobs currently held by workers with disabilities may, however, greatly constrain their ability to benefit from the increased availability of working from home. We estimate that only $34 \%$ are in occupations with a high potential for home-based work, compared to $40 \%$ of workers without disabilities. Some jobs simply require face-to-face interaction, such as being a home health aide, food server, or haircutter, and others require working in a location directly 
Table 9 Potential for jobs to be done at home

\section{Percent of jobs} that could be done entirely at home

Percent of jobs done primarily from home, 2014-2018

NAICS Code

11

13

15

17

19

23

25

27

29

31

33

35

37

39

41

43

45

47

49

51

53

(1)

Management occupations

Business and Financial Operations Occupations

Computer and Mathematical Occupations

Architecture and Engineering Occupations

Life, Physical, and Social Science Occupations

Community and Social Service Occupations

Legal Occupations

Education, Training, and Library Occupations

Arts, Design, Entertainment, Sports, and Media Occupations

Healthcare Practitioners and 5.0\% Technical Occupations

Healthcare Support Occu- $\quad 2.0 \%$ pations

Protective Service Occupa- $\quad 6.0 \%$ tions

Food Preparation and Serv- $\quad 0.0 \%$ ing Related Occupations

Building and Grounds Cleaning and Maintenance Occupations

Personal Care and Service Occupations

Sales and Related Occupations

Office and Administrative $\quad 65.0 \%$ Support Occupations

Farming, Fishing, and Forestry Occupations

Construction And Extraction Occupations

Installation, Maintenance, and Repair Occupations

Production Occupations

Transportation and Material

Moving Occupations

Correlation of columns (1) and (2)

Correlation of columns (1) and (3)

$0.0 \%$

$26.0 \%$

$28.0 \%$

(2)

$87.0 \%$

$88.0 \%$

$100.0 \%$

$61.0 \%$

$54.0 \%$

$37.0 \%$

$97.0 \%$

$98.0 \%$

$76.0 \%$

$8.2 \%$

$9.6 \%$

$10.5 \%$

$4.8 \%$

$4.7 \%$

$4.2 \%$

$6.4 \%$

$3.0 \%$

$16.4 \%$

$2.3 \%$

$5.9 \%$

$1.5 \%$

$1.2 \%$

$3.2 \%$

$9.5 \%$

$6.3 \%$

$4.4 \%$

$5.5 \%$

$2.8 \%$

$2.8 \%$

$1.9 \%$

$1.9 \%$

$1.0 \%$

$3.0 \%$

0.59

$-0.68$

Based on current distributions, estimated percent of jobs that could be done entirely at home for:

Workers with disabilities

$39.5 \%$

$34.0 \%$
$3.9 \%$

Percent of workers who have disabilities, 2014-2018

(3)

$4.5 \%$

$4.3 \%$

$3.8 \%$

$4.0 \%$

$3.6 \%$

$6.1 \%$

$4.3 \%$

$4.4 \%$

$4.8 \%$

$7.1 \%$

$5.7 \%$

$5.9 \%$

$8.7 \%$

$6.1 \%$

$5.4 \%$

$5.9 \%$

$6.1 \%$

$5.4 \%$

$6.3 \%$

$7.0 \%$

$7.1 \%$

Sources: Column 1 data are from Dingel and Neiman (2020); columns 2 and 3 data are calculated from 2014 to 2018 American Community Survey microdata 
with co-workers or with large capital investments, such as on an assembly line. Workers with disabilities are currently more likely to be in these kinds of low-level service and blue-collar occupations. The pandemic may lead employers to rethink some of these jobs to be more amenable to work at home. For example, some work requiring team-based interaction may be moved to virtual conferences, and many administrative tasks may be migrated on-line. Technology is clearly a critical factor in work at home [49]: even manufacturing jobs may be increasingly done at home with new technologies such as 3D printing.

The question of intersectionality with gender, race, and ethnicity is important. We found that the disability gap in home-based work was slightly smaller but still strongly significant among Blacks and Hispanics/Latinos (Table 2). Given that the pandemic may have hit these groups harder, it will be interesting to see how disability combines with these other characteristics in determining the effects of home-based work on Black and Hispanic/Latino workers with disabilities.

A potential barrier to home-based work for people with disabilities is that a large number of such jobs now require Internet access. As shown in Table 2, people with disabilities are more likely than those without disabilities to work at home whether or not their homes have Internet access, but it is clear that Internet access opens more possibilities for work at home. The pandemic has made broadband access even more important. From the 2018 ACS, we calculate that people with disabilities are less likely to live in homes with Internet access, constraining their employment prospects. Although there has been improvement, 17\% of non-employed working-age people with disabilities lived in a home without Internet access in 2018, compared to 9\% of people without disabilities. Any substantial expansion of employment that includes home-based work is therefore likely to involve efforts to increase Internet access in homes of people with disabilities.

We are not claiming that increased opportunity to work at home is an unmitigated good for people with disabilities. As noted initially, there are disadvantages to home-based work, such as social isolation and career-growth limitations. Clearly it should not be used by employers to avoid making reasonable accommodations or to avoid incorporating workers with disabilities into workplace cultures and making efforts to ensure an environment that values and respects all employees.

\section{Conclusion}

The pandemic can be seen as a massive test of employers' ability and willingness to accommodate workers. It may radically transform the way we think about and perform our jobs. Our key question is what implications the pandemic will have for the employment of people with disabilities, with a focus on the role of home-based work. Our answers are necessarily speculative, but we inform our conclusions by analyzing pre-COVID data over the 2009-2019 period on disability and work at home. The key results are:

- Among both employees and self-employed workers, workers with disabilities are more likely to work at home than otherwise-similar workers without disabilities.

- Rates of working primarily at home are higher among workers with disabilities across broad occupational, gender, race/ethnicity, age, and education groups, as well as when considering whether the person lives alone, with children, or elders, except that there is a little difference by disability status among middle-aged workers.

- Rates of working primarily at home are highest for people with mobility impairments, difficulty with self-care, and difficulty going outside alone.

- The rates of working primarily at home increased for workers both with and without disabilities over the 20092018 period, but increased more for workers without disabilities, so the disability gap in home-based work narrowed over this period.

- Compared to on-site work, workers with disabilities doing home-based work face slightly larger wage gaps relative to workers without disabilities.

- Despite their higher current likelihood of working at home, workers with disabilities are currently less likely than those without disabilities to work in occupations with high potential for home-based work.

What further research is needed? It will be interesting to see how home-based work evolves as the economy recovers over the next several years. Workers without disabilities may discover many advantages of working from home and catch up to the rate of home-based work for people with disabilities. But as suggested here, employers may find that home-bound people with disabilities are a valuable pool for re-imagined jobs. Along with the overall rate of home-based work, it will be valuable to analyze two questions concerning occupation: which occupations will have increased rates of home-based work, and whether there will be a shift in the occupational distribution of workers both with and without disabilities if they gravitate to occupations with greater opportunities for home-based work.

Another important research topic is the compensation levels of home-based workers. We find that the disability pay gap is just as large, or larger, among home-based workers than among on-site workers, suggesting a similar treatment of people with disabilities in the two settings. It is possible, however, that pay patterns could change as employers rethink work tasks and measures of productivity. Workers 
with disabilities may especially benefit if they are increasingly judged on their work tasks rather than on the basis of stereotypes that shape their current pay and work conditions [12].

While standard data sources such as the ACS, CPS, and ATUS will provide valuable data on trends in home-based work and its relation to demographics and pay, it will be important to collect new data on the experiences of workers with disabilities who are doing home-based work. Such data may include new quantitative and qualitative data that gather information on the perceived advantages and disadvantages of home-based work.

Some of the important topics to be considered are: (1) social isolation-do virtual meetings effectively substitute for in-person meetings in helping people with and without disabilities stay connected, and are there enough meaningful opportunities for collaborating and socializing with coworkers?; (2) opportunities for training, promotions, and raises-do home-based workers feel (and are they in actuality) "out of sight, out of mind" when it comes to career growth?; (3) work-family balance-does home-based work help people manage their home responsibilities with children and elders, or does this create too many distractions for productive work?; (4) intersectionality-does homebased work have similar effects on workers with disabilities across racial, ethnic, and gender categories?; (5) managing one's disability - does home-based work help people better cope with the time, energy, and physical demands posed by many disabilities, thereby improving their work-life experience, and even their health?; (6) worker organizing-is it harder for home-based workers to join together, through unions or other collective means, to demand better pay and treatment?; and (7) disability inclusive employment policy-does the current prevalence of home-based work require new or revised policies and laws to combat discrimination and support reasonable accommodation, equal pay, and equal employment opportunity for people with disabilities [50]?

In focusing on working from home, we do not want to ignore the cataclysmic loss of millions of jobs during the pandemic, which hit people with disabilities especially hard. Without minimizing the current devastation, it is worth considering how the structure of work may change when the crisis abates, and the economy eventually recovers. Will working remotely become a viable lasting option for more of us, or will it continue to be viewed as a special benefit or accommodation outside the "normal" way most people do our jobs? The way we answer this question has the potential to open up job opportunities for people with disabilities and help them achieve greater economic and social equality.

\section{Compliance with Ethical Standards}

Conflict of interest Author Lisa A. Schur declares that she has no conflict of interest. Author Mason Ameri declares that he has no conflict of interest. Author Douglas Kruse declares that he has no conflict of interest.

\section{References}

1. Ali M, Schur S, Blanck P. What types of jobs do people with disabilities want? J Occup Rehabil. 2011;21:199-210.

2. Silvermann B. Many full-time employees in the U.S. want to work remotely, even after the COVID-19 crisis has passed. But can working from home actually save companies money? In: Business. com. 16 June 2020. https://www.business.com/articles/workingfrom-home-save-money/. Accessed 14 Oct. 2020.

3. Reynolds BW. The mental health benefits of remote and flexible work. In: Mental Health America. n.d. https://www.mhana tional.org/blog/mental-health-benefits-remote-and-flexible-work. Accessed 14 Oct 2020.

4. Schwartz N. Working from home poses hurdles for employees of color. New York Times. 6 Sept 2020.

5. World Health Organization. Disability considerations during the COVID-19 outbreak. WHO/2019-nCoV/Disability/2020.1. 2019.

6. Wagstaff B, Quasius J. The ADA, telework, and the post-pandemic workplace. In: The Regulatory Review. 2020. https://www.there greview.org/2020/09/07/wagstaff-quasius-ada-telework-postpandemic-workplace/. Accessed 14 Oct 2020.

7. U.S. Bureau of Labor Statistics. Persons with a Disability: Labor Force Characteristics-2019. USDL-20-0339. 2020.

8. Bonaccio S, Connelly CE, Gellatly IR, Jetha A, Ginis K. The participation of people with disabilities in the workplace across the employment cycle: employer concerns and research evidence. J Bus \& Psychol. 2019;35(2):1-24.

9. Baert S. Wage subsidies and hiring chances for the disabled: some causal evidence. European J Health Econ. 2016;17:71-86.

10. Baert S. Hiring discrimination: An overview of (almost) all correspondence experiments since 2005. In: Gaddis S, editor. Audit studies: behind the scenes with theory, method, and nuance. Cham Switzerland: Springer; 2018. p. 63-77.

11. Ameri M, Schur L, Adya M, Bentley S, McKay P, Kruse D. The disability employment puzzle: A field experiment on employer hiring behavior. ILR Rev. 2018;71:329-364.

12. Ren L, Paetzold R, Colella A. A meta-analysis of experimental studies on the effects of disability on human resource judgments. Hum Resour Manag Rev. 2008;18:191-203.

13. Schur L, Han K, Kim A, Ameri M, Blanck P, Kruse D. Disability at work: a look back and forward. J Occup Rehabil. 2017;27(4):482-497.

14. Schur L, Nishii L, Adya M, Kruse D, Bruyère SM, Blanck P. Accommodating employees with and without disabilities. Hum Resour Manag. 2014;53(4):593-621.

15. Baldwin ML, Johnson WG. A critical review of studies of discrimination against workers with disabilities. In: Rodgers WM, editor. Handbook on the economics of discrimination. Northampton, MA: Edward Elgar Publishing; 2006. p. 119-160.

16. Kruse D, Schur L, Rogers S, Ameri M. Why do workers with disabilities earn less? Occupational job requirements and disability discrimination. Br J Ind Relat. 2018;56(4):798-834.

17. Mitra S, Kruse D. Are workers with disabilities more likely to be displaced? Int J Hum Resour Manag. 2016;27(14):1550-1579. 
18. Bloom N, Liang J, Roberts J, Ying ZJ. Does working from home work? Evidence from a Chinese experiment. Q J Econ. 2015;130(1):165-218.

19. Maurer R. Study finds productivity not deterred by shift to remote work. In: HR News. Society for Human Resource Management. 2020. https://www.shrm.org/hr-today/news/hr-news/pages/ study-productivity-shift-remote-work-covid-coronavirus.aspx. Accessed 14 Oct 2020.

20. Martin BH, MacDonnell R. Is telework effective for organizations? Manag Res Rev. 2012;35(7):602-616.

21. Mekonnen T. Examining the effect of teleworking on employees' job performance. Doctoral dissertation, Walden University. 2013.

22. Lavelle J. Gartner CFO Survey Reveals $74 \%$ Intend to Shift Some Employees to Remote Work Permanently. In: Newsroom Press Releases. Gartner. 2020. https://www.gartner.com/en/newsroom/ press-releases/2020-04-03-gartner-cfo-surey-reveals-74-percentof-organizations-to-shift-some-employees-to-remote-work-perma nently2. Accessed 14 Oct 2020.

23. Baert S, Lippens L, Moens E, Weytjens J, Sterkens P. The COVID-19 crisis and telework: a research survey on experiences, expectations and hopes. IZA Discussion Paper 13229. May 2020.

24. Allen TD, Golden TD, Shockley KM. How effective is telecommuting? Assessing the status of our scientific findings. Psychol Sci in the Public Interest. 2015;16(2):40-68.

25. Guynn J. Yahoo CEO Marissa Mayer causes uproar with telecommuting ban. Los Angeles Times. 26 Feb 2013.

26. Avery C, Zabel D. The flexible workplace: a sourcebook of information and research. Westport CT: Quorum Books; 2001.

27. Hammer LB, Neal MB, Newsom JT, Brockwood KJ, Colton CL. A longitudinal study of the effects of dual-earner couples' utilization of family-friendly workplace supports on work and family outcomes. J Appl Psychol. 2005;90(4):799-810.

28. Hamilton E. Bringing work home: advantages and challenges of telecommuting. Center for Work \& Family. 2002.

29. Shockley KM, Allen TD. When flexibility helps: another look at the availability of flexible work arrangements and work-family conflict. J Vocat Behav. 2007;71(3):479-493.

30. Solís M. Moderators of telework effects on the work-family conflict and on worker performance. Eur J Manag \& Bus Econ. 2017;6(1):21-34.

31. Madsen SR. The effects of home-based teleworking on workfamily conflict. Hum Resour Dev Q. 2003;14(1):35-58.

32. Igeltjørn A, Habib L. Homebased telework as a tool for inclusion? A literature review of telework, disabilities and work-life balance. In: International Conference on Human-Computer Interaction. Springer, Cham, 2020. pp. 420-436.

33. Linden M, Milchus K. Teleworkers with disabilities: characteristics and accommodation use. Work. 2014;47(4):473-483.

34. Giovanis E. Ozdamar O. Accommodating employees with disabilities: the role of flexible employment schemes in Europe. 2019. https://doi.org/10.2139/ssrn.3441925.

35. Moon NW, Linden MA, Bricout JC, Baker P. Telework rationale and implementation for people with disabilities: considerations for employer policymaking. Work. 2014;48(1):105-115.
36. Blanck P, Abdul-Malak Y, Adya M, Hyseni F, Killeen M, Altunkol Wise F. Diversity and inclusion in the American legal profession: first phase findings from a national study of lawyers with disabilities and lawyers who identify as LGBTQ+. Univ DC Law Rev. 2020;23:23-87.

37. Blanck P, Hyseni F, Altunkol Wise F. Diversity and inclusion in the American legal profession: workplace accommodations for lawyers with disabilities and lawyers who identify as LGBTQ+. J Occup Rehabil. 2020. https://doi.org/10.1007/s10926-020-09938 $-3$

38. Baker P, Moon NW, Ward AC. Virtual exclusion and telework: barriers and opportunities of technocentric workplace accommodation policy. Work. 2006;27(4):421-430.

39. West MD, Anderson J. Telework and employees with disabilities: accommodation and funding options. J Vocat Rehab. 2005;23(2):115-122.

40. McNaughton D, Rackensperger T, Dorn D, Wilson N. "Home is at work and work is at home": telework and individuals who use augmentative and alternative communication. Work. 2014;48(1):117-126.

41. Mulvaney E. Coronavirus telework tests disability accommodation defense (2). In: Daily Labor Report. Bloomberg Law. 2020. https ://news.bloomberglaw.com/daily-labor-report/coronavirus-telew ork-challenges-disability-accommodation-defense. Accessed 14 Oct 2020.

42. Pabilonia SW, Vernon V. Telework and time use in the United States. Global Labor Organization. Discussion Paper 546. 2020.

43. Dingel JI, Neiman B. How many jobs can be done at home? National Bureau of Economic Research. Discussion Paper 26948. 2020.

44. Harpur P, Blanck P. Gig workers with disabilities: opportunities, challenges, and regulatory response. J Occup Rehabil. 2020. (this issue).

45. U.S. EEOC. Work at home/telework as a reasonable accommodation. EEOC-NVTA-2003-1. 2003.

46. Kaye HS, Jans LH, Jones EC. Why don't employers hire and retain workers with disabilities? J Occup Rehabil. 2011;21(4):526-536.

47. Beery Z. When the world shut down, they saw it open. New York Times. 24 Aug 2020.

48. Campoamor, D. Disabled people react to Coronavirus work from home accommodations. TeenVogue. 24 March 2020.

49. Shin SK. The convergence of technology and welfare: effect of the development of ICT on the work environment and job placement for people with disabilities. J Digit Converg. 2019;17(7):417-422.

50. Blanck P. Disability inclusive employment and the accommodation principle: emerging issues in research, policy, and law. $\mathrm{J}$ Occup Rehabil. 2020. (this issue)

Publisher's Note Springer Nature remains neutral with regard to jurisdictional claims in published maps and institutional affiliations. 